\title{
POTENSI KAMPUNG KEDUNGGUDEL SEBAGAI KAMPUNG WISATA DI KELURAHAN KENEP SUKOHARJO
}

\section{Dina Putri Wijayanti}

Program Studi Arsitektur Fakultas Teknik Universitas Muhammadiyah Surakarta e-mail: Dinawijayanti25598@gmail.com

\section{Indrawati}

Program Studi Arsitektur Fakultas Teknik Universitas Muhammadiyah Surakarta e-mail: indrawati@ums.ac.id

\begin{abstract}
ABSTRAK
Kampung Kedunggudel di Kelurahan Kenep Kabupaten Sukoharjo memiliki banyak daya tarik yang terdiri dari daya tarik alam, budaya dan manusia. Kampung ini menarik untuk diangkat sebagai kampong wisata. Pengembangan kampung wisata diperlukan sarana dan prasarana yang memadai serta atraksi yang tepat untuk mengelola daya tarik yang ada, sehingga dapat menarik wisatawan untuk berkunjung. Penelitian ini bertujuan untuk mengetahui daya tarik yang terdapat di Kampung Kedunggudel sehingga terpilih menjadi kampung wisata, serta mengetahui atraksi yang dapat dikembangkan. Metode yang digunakan dalam penelitian ini yaitu wawancara, observasi dan dokumentasi. Metode analisis data yang digunakan yaitu metode SWOT. Hasil penelitian ini menunjukkan bahwa kampung ini memiliki daya tarik alam, budaya dan manusia. Sarana prasarana yang tersedia yaitu akomodasi, toko kelontong, pasar tradisional, salon, jalan, listrik, air bersih, air minum, pelayanan informasi dan masjid. Sedangkan sarana dan prasarana yang belum tersedia yaitu tempat makan, transportasi, papan petunjuk arah dan toilet umum. Atraksi yang tersedia sebatas pembelajaran, belum bersifat rekreatif. Keberhasilan pengembangan kampong ini menuntut adanya kerjasama antara masyarakat dan pemerintah melalui keberagaman atraksi dan beragam sarana prasarana yang dibutuhkan dalam kampung wisata.
\end{abstract}

KATA KUNCI: atraksi, potensi, sarana prasarana, wisata

\section{PENDAHULUAN}

Kampung Kedunggudel merupakan salah satu kampung di Kelurahan Kenep Kabupaten Sukoharjo yang memiliki banyak potensi. Beberapa potensi yang ada di kampung ini adalah potensi industri rumahan dan potensi sejarah. Potensi yang ada sesungguhnya dapat dikembangkan menjadi kampung wisata, dan tentunya menjadi magnet wisatawan untuk datang berkunjung. Pengelolaan potensi daerah menjadi kampong wisata, diperlukan kerjasama antara pemerintah dengan masyarakat setempat. Hal in bertujuan untuk membangun dan memperkuat kemampuan dalam berorganisasi dengan masyarakat lokal, dalam menghadapi wisatawan dalam jumlah besar. Pengembangan potensi ini memiliki peranan penting di masa yang akan datang karena dapat memberikan wawasan baru terhadap wisatawan dan memberikan dampak ekonomi terhadap masyarakat sekitar serta dapat meningkatkan pendapatan daerah.

Kampung Kedunggudel Sukoharjo berada di pinggiran kota, yang melintas di dekatnya adalah Sungai Bengawan Solo. Industri rumahan yang berkembang adalah pembuatan batik dan jenang (makanan legit atau manis khas Jawa Tenah). Potensi lain adalah adanya fasilitas panduwisata kampung serta atraksi, namun masih kurang memadai, sehingga perlu dilakukan penelitian yang bertujuan: 1) mengidentifikasi potensi yang terdapat di Kampung Kedunggudel sehingga menjadi destinasi wisata yang dipilih oleh masyarakat, 2) mengidentifikasi atraksi yang terdapat di Kampung Kedunggudel 3) mengidentifikasi ketersediaan sarana dan prasarana penunjang wisata yang ada di Kampung Kedunggudel.

Kampung atau desa wisata merupakan tempat sekumpulan wisatawan tinggal sementara di sebuah kampong atau desa yang jauh dari perkotaan, dengan tujuan untuk mempelajari kehidupan dan lingkungan pedesaan dengan suasana tradisional (Pujani, 2017). Menurut Muliawan (dalam Atmoko, 2014) kriteria desa wisata yaitu:

1. Mempunyai potensi keunikan dan daya tarik wisata yang khas.

2. Mempunyai fasilitas pendukung yang memadai.

3. Mempunyai interaksi dengan wisatawan.

4. Masyarakat ikut berpartisipasi terhadap pengembangan desa wisata.

Menurut Karyono (dalam Atmoko, 2014) terdapat komponen pengembangan desa wisata yaitu: 1) Atraksi menurut Pearce (dalam Ramadhan, 2016) dibagi dibagi menjadi dua jenis yaitu pertama Site Attraction yang bersifat permanen dengan lokasi yang 
tetap dan kegiatan atraksinya hanya dapat dinikmati di lokasi tersebut. Ada beberapa jenis atraksi fisik yaitu atraksi wisata alam, atraksi wisata buatan, amenitas/ fasilitas dan aksesbilitas. Kedua adalah Event Attraction yang sifatnya sementara dan lokasinya dapat berpindah tempat, misalnya upacara adat, pagelaran, konvensi, pertandingan dan lain-lain, 2) Akomodasi, 3) Unsur kelembagaan, 4) Fasilitas pendukung wisata, 5) Infrastruktur, 6) Transportasi, 7) Sumber daya alam dan 8) Social budaya.

Hary Hermawan (2017) menyebutkan bahwa terdapat tiga jenis potensi suatu daerah, yang dapat dikembangkan sebagai daya tarik wisata, yaitu:

1. Potensi Alam adalah macam-macam flora fauna di suatu wilayah yang memiliki bentang alam.

2. Potensi Kebudayaan adalah hasil cipta, rasa dan karsa manusia yang berupa adat istiadat, kerajinan tangan, kesenian, peninggalan sejarah dan lainnya.

3. Potensi Manusia berupa tarian daerah, pertunjukan, pementasan seni budaya suatu daerah dan dapat berupa sumber daya yang turut serta dalam pengelolaan pariwisata.

Sementara itu menurut Ghani (2017) sarana untuk pariwisata dibagi menjadi tiga macam:

1. Sarana Pokok berupa travel agent, tour operator, angkutan wisata, rumah makan, akomodasi, objek wisata dan atraksi wisata.

2. Sarana Pelengkap berupa toko kelontong, toko pakaian, salon dan lain-lain.

3. Sarana Penunjang spa, salon, night club dan lainlain.

Adapun Rengkung (2019) mengatakan prasarana terdiri dari (1) Prasarana aksesbilitas meliputi jalan, jembatan dan pemberhentian transportasi (2) Instalasi listrik dan air bersih (3) Sistem irigasi (4) Prasarana kesehatan (5) Prasarana keamanan, pendidikan dan hiburan.

\section{METODE PENELITIAN}

Metode pengumpulan data menggunakan observasi, wawancara, dan dokumentasi. Observasi dilakukan dengan mengamati langsung kondisi di Kampung Kedunggudel. Wawancara dilakukan dengan bertatap muka secara langsung dan memberikan beberapa pertanyan kepada responden sesuai fokus penelitian. Sedangkan dokumentasi untuk mendapatkan data gambar di lapangan. Uraian data sesuai Tabel 1.

Tabel 1. Aspek pengumpulan data

\begin{tabular}{ll}
\hline Fokus & Aspek yang dituju \\
\hline Potensi alam & Sungai Bengawan Solo \\
\hline Potensi budaya & Industri batik \\
\hline
\end{tabular}

\begin{tabular}{ll}
\hline Fokus & Aspek yang dituju \\
\hline Potensi manusia & Industri jenang \\
\hline Sarana pokok & Jempat makan \\
\cline { 2 - 2 } & Akomodasi \\
\hline Sarana pelengkap & Toko kelontong \\
\cline { 2 - 2 } & Pasar tradisional \\
\hline Sarana penunjang & Salon \\
\hline Aksesbilitas & Jalan \\
\cline { 2 - 2 } & Transportasi \\
\cline { 2 - 2 } & Papan petunjuk arah \\
\hline Utilitas & Listrik \\
\cline { 2 - 2 } & Air bersih \\
\cline { 2 - 2 } & Persediaan air minum \\
\cline { 2 - 2 } & Toilet \\
\hline Site Attraction & Pelayanan informasi \\
\hline Jaringan pelayanan & Masjid \\
\hline
\end{tabular}

Sumber: data lapangan (2019)

Data dianalisis menggunakan metode SWOT sesuai tujuan dari penelitian (lihat Tabel 2).

Tabel 2. Metode analisis data SWOT

\begin{tabular}{|c|c|c|}
\hline $\begin{array}{l}\text { Eksternal / } \\
\text { Interal }\end{array}$ & Opportunities (O) & Treaths $(T)$ \\
\hline Strengths (S) & $\begin{array}{l}\text { Strategi yang } \\
\text { menggunakan } \\
\text { kekuatan untuk } \\
\text { memanfaatkan } \\
\text { peluang } \\
\end{array}$ & $\begin{array}{l}\text { Strategi yang } \\
\text { menggunakan } \\
\text { kekuatan untuk } \\
\text { mengatasi } \\
\text { ancaman } \\
\end{array}$ \\
\hline $\begin{array}{l}\text { Weaknesses } \\
\text { (W) }\end{array}$ & $\begin{array}{l}\text { Strategi yang } \\
\text { meminimalkan } \\
\text { kelemahan untuk } \\
\text { memanfaatkan } \\
\text { peluang }\end{array}$ & $\begin{array}{l}\text { Strategi yang } \\
\text { meminimalkan } \\
\text { kelemahan dan } \\
\text { menghindari } \\
\text { ancaman }\end{array}$ \\
\hline
\end{tabular}

Sumber: Setyawan, 2015

\section{HASIL DAN PEMBAHASAN}

\section{Lokasi Penelitian}

Lokasi penelitian berada di Kampung Kedunggudel, Kelurahan Kenep, Kecamatan Sukoharjo, Kabupaten Sukoharjo. Kampung Kedunggudel merupakan Kawasan prioritas Kelurahan Kenep yang menjadi prioritas penanganan dalam penyusunan Rencana Tindak Penataan Lingkungan Permukiman (RTPLP) yang meliputi $3 \mathrm{RW}$ dan $11 \mathrm{RT}$ dengan total luas wilayah $403.360 \mathrm{~m}^{2}$. Wilayah penelitian meliputi sebagian besar pemukiman penduduk, tempat usaha 
kecil berupa industri rumah tangga yang ada di RW 01 , RW 02, dan RW 03 (lihat gambar 1).

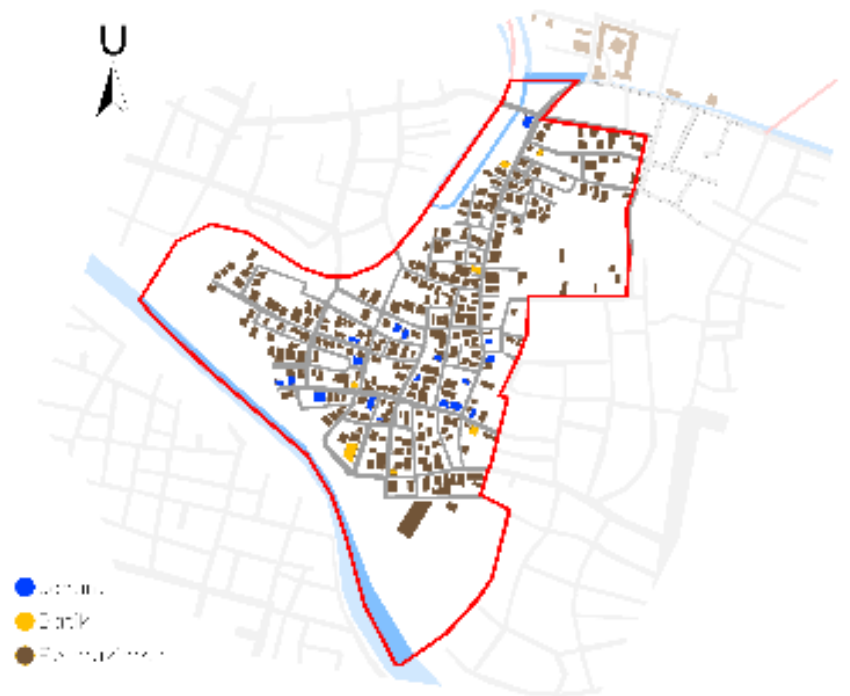

Gambar 1 Pemetaan industri rumah tangga Sumber : Dokumen penulis, 2019

Jumlah wisatawan pada tahun 2019 mencapai 1 juta pengunjung. Kegiatan yang dilakukan pengunjung yaitu belajar dengan sistem outing class dan beberapa pelatihan dari berbagai universitas, seperti Universitas Muhammadiyah Surakarta, Universitas Gadjah Mada dan Universitas Veteran, yang berkaitan dengan industri batik dan jenang. Pengunjung yang datang menggunakan kendaraan bis, kereta kelinci, mobil, dan sepeda motor.

\section{Hasil Penelitian Analisa SWOT}

Hasil analisis SWOT dilakukan terpisah, seperti terurai dalam Table 3 sampai Tabel 6.

Table 3 Hasil penelitian berdasarkan kekuatan

\begin{tabular}{ll}
\hline & Kekuatan (Strengths) \\
Bungai & Sungai Bengawan Solo memiliki sejarah \\
Solo & yang sangat berkaitan dengan \\
& $\begin{array}{l}\text { perkembangan industri rumah tangga } \\
\text { yang ada di Kampung Kedunggudel ini. }\end{array}$ \\
\hline Industri & Batik di kampung ini ada yang memiliki \\
batik & ciri khas tersendiri yaitu motif batik Solo \\
& dan motif kebun jeruk seruh ayu. \\
\hline Industri & Pembuatan jenang di lakukan pada sore \\
jenang & hari dan dijual di pasar pada pagi hari \\
& sehingga persediaan jenang selalu fresh. \\
& Jenang ini dibuat dari beras, ketan, gula \\
& jawa dan kelapa. \\
\hline Jasa & Terdapat pemandu wisata dari \\
& masyarakat setempat. Bapak Agus \\
& Samiyono merupakan salah satunya \\
& karena beliau yang mendirikan \\
& paguyuban untuk mengembangkan \\
& potensi desa wisata. \\
\hline Tempat & Tersedia tempat makan berupa \\
angkringan yang sederhana.
\end{tabular}

\begin{tabular}{|c|c|}
\hline & Kekuatan (Strengths) \\
\hline Akomodasi & $\begin{array}{l}\text { Sudah tersedia akomodasi berupa } \\
\text { penginapan di rumah warga. Jumlah } \\
\text { penginapan dapat menyesuaikan jumlah } \\
\text { wisatawan yang akan menginap. }\end{array}$ \\
\hline $\begin{array}{l}\text { Toko } \\
\text { kelontong }\end{array}$ & $\begin{array}{l}\text { Toko kelontong yang tersedia berjumlah } \\
\text { kurang lebih } 10 \text { toko sehingga tidak sulit } \\
\text { menemukannya. }\end{array}$ \\
\hline $\begin{array}{l}\text { Pasar } \\
\text { tradisional }\end{array}$ & $\begin{array}{l}\text { Terdapat pasar tradisional yang menjual } \\
\text { berbagai keperluan dapur dan rumah } \\
\text { tangga. }\end{array}$ \\
\hline Salon & $\begin{array}{l}\text { Salon memiliki pelayanan aneka } \\
\text { perawatan rambut, rias pengantin dan } \\
\text { fotografi wedding. }\end{array}$ \\
\hline Jalan & $\begin{array}{l}\text { Jalan masuk utama melalui Jl. KH } \\
\text { Samanhudi dapat dilewati bus pariwisata. } \\
\text { Kondisi jalan baik tidak berlubang. }\end{array}$ \\
\hline Transportasi & $\begin{array}{l}\text { Terdapat transportasi umum untuk } \\
\text { menuju Kampung Kedunggudel. }\end{array}$ \\
\hline $\begin{array}{l}\text { Papan } \\
\text { petunjuk } \\
\text { arah }\end{array}$ & $\begin{array}{l}\text { Papan petunjuk tersedia di gerbang } \\
\text { masuk di JI KH Samanhudi. }\end{array}$ \\
\hline Listrik & $\begin{array}{l}\text { Aliran listrik di Kampung Kedunggudel } \\
\text { sudah merata ke seluruh rumah warga. }\end{array}$ \\
\hline Air bersih & $\begin{array}{l}\text { Ketersediaan air bersih di Kampung } \\
\text { Kedunggudel melimpah. }\end{array}$ \\
\hline $\begin{array}{l}\text { Persediaan } \\
\text { air minum }\end{array}$ & $\begin{array}{l}\text { Persediaan air minum mudah ditemui di } \\
\text { toko kelontong sekitar. }\end{array}$ \\
\hline Toilet & $\begin{array}{l}\text { Toilet umum hanya ada di masjid yang } \\
\text { berada di kampung ini. }\end{array}$ \\
\hline $\begin{array}{l}\text { Pelayanan } \\
\text { informasi }\end{array}$ & $\begin{array}{l}\text { Untuk saat ini pusat pelayanan informasi } \\
\text { dapat dijumpai di kantor Pokdarwis yang } \\
\text { berada di komplek Kelurahan Kenep. }\end{array}$ \\
\hline Masjid & $\begin{array}{l}\text { Masjid Darussalam merupakan masjid } \\
\text { tertua di kampung ini dan peninggalan } \\
\text { para alim ulama. Berdiri sejak zaman } \\
\text { penyebaran agama Hindu Budha di Jawa. }\end{array}$ \\
\hline $\begin{array}{l}\text { Kunjungan } \\
\text { pembelajar } \\
\text { an }\end{array}$ & $\begin{array}{l}\text { Wisatawan dapat melakukan kunjungan } \\
\text { sambil belajar proses pembuatan batik } \\
\text { dan jenang di rumah produksi dipandu } \\
\text { oleh pemandu wisata maupun pemilik } \\
\text { usaha. }\end{array}$ \\
\hline
\end{tabular}

Sumber : analisis penulis, 2019

Table 4 Hasil penelitian berdasarkan kelemahan

\begin{tabular}{|c|c|}
\hline & Kelemahan (Weakness) \\
\hline Sungai & Sungai ini belum difungsikan kembali \\
\hline Solo & $\begin{array}{l}\text { kurangnya kerjasama pengelolaan } \\
\text { antara pemerintah dan masyarakat dan } \\
\text { sedikitnya jumlah pengunjung. }\end{array}$ \\
\hline Industri batik & $\begin{array}{l}\text { Tidak ada ciri khas lokal motif batik, } \\
\text { dimana setiap pemilik batik memiliki } \\
\text { motif masing-masing yang berbeda. }\end{array}$ \\
\hline $\begin{array}{l}\text { Industri } \\
\text { jenang }\end{array}$ & $\begin{array}{l}\text { Jenang hanya bisa bertahan 2-3 hari jika } \\
\text { tidak disimpan di kulkas. }\end{array}$ \\
\hline Jasa & $\begin{array}{l}\text { Belum banyak pemandu wisata yang } \\
\text { tersedia. }\end{array}$ \\
\hline $\begin{array}{l}\text { Tempat } \\
\text { makan }\end{array}$ & $\begin{array}{l}\text { Tempat makan yang tersedia hanya } \\
\text { mampu menampung sekitar } 20 \text { orang. }\end{array}$ \\
\hline
\end{tabular}




\begin{tabular}{|c|c|}
\hline & Kelemahan (Weakness) \\
\hline Akomodasi & $\begin{array}{l}\text { Belum banyak rumah warga yang } \\
\text { menyediakan rumahnya sebagai } \\
\text { penginapan. Tetapi selalu diusahakan } \\
\text { sesuai kebutuhan. }\end{array}$ \\
\hline $\begin{array}{l}\text { Toko } \\
\text { kelontong }\end{array}$ & Kurang lengkap barang yang dijual \\
\hline $\begin{array}{l}\text { Pasar } \\
\text { tradisional }\end{array}$ & Jam buka pedagang pasar kurang lama. \\
\hline Salon & $\begin{array}{l}\text { Hanya terdapat satu salon dalam } \\
\text { kampung ini. }\end{array}$ \\
\hline Jalan & $\begin{array}{l}\text { Lebar jalan hanya dapat dilewati bus } \\
\text { untuk satu arah. Sedikit kesulitan untuk } \\
\text { dilewati bus dua arah. }\end{array}$ \\
\hline Transportasi & $\begin{array}{l}\text { Transportasi umum hanya menjangkau } \\
\text { sampai gerbang masuk ke Kampung } \\
\text { Kedunggudel dan tidak melintas di } \\
\text { dalam kampung. Tidak tersedia } \\
\text { transportasi wisata. }\end{array}$ \\
\hline $\begin{array}{l}\text { Papan } \\
\text { petunjuk } \\
\text { arah }\end{array}$ & $\begin{array}{l}\text { Tidak tersedia papan petunjuk arah } \\
\text { yang menunjukkan arah ke berbagai } \\
\text { industri. }\end{array}$ \\
\hline Listrik & $\begin{array}{l}\text { Tidak tersedia genset untuk sumber } \\
\text { listrik ketika terjadi pemadaman listrik. }\end{array}$ \\
\hline Air bersih & Tidak tersedia cadangan air bersih. \\
\hline $\begin{array}{l}\text { Persediaan } \\
\text { air minum }\end{array}$ & Tidak tersedia cadangan air minum. \\
\hline Toilet & $\begin{array}{l}\text { Hanya dapat dijangkau bila berada di } \\
\text { sekitar masjid. }\end{array}$ \\
\hline $\begin{array}{l}\text { Pelayanan } \\
\text { informasi }\end{array}$ & $\begin{array}{l}\text { Letak kantor Pokdarwis berjarak kurang } \\
\text { lebih } 100 \text { m dari pemukiman warga } \\
\text { Kampung Kedunggudel dan hanya buka } \\
\text { hingga siang ataupun sore. }\end{array}$ \\
\hline Masjid & Letak stategis \\
\hline $\begin{array}{l}\text { Kunjungan } \\
\text { pembelajaran }\end{array}$ & $\begin{array}{l}\text { Belum menyediakan tempat khusus } \\
\text { untuk belajar membatik dan membuat } \\
\text { jenang. }\end{array}$ \\
\hline
\end{tabular}

Sumber : analisis penulis, 2019

Table 5 Hasil penelitian berdasarkan peluang

\begin{tabular}{ll}
\hline & \multicolumn{1}{c}{ Peluang (Opportunities) } \\
\hline Sungai & Dibutuhkan kerjasama antara \\
Solo & $\begin{array}{l}\text { pemerintah dan masyarakat untuk } \\
\text { mengembangkan fungsi sungai ini } \\
\text { supaya menjadi objek wisata yang } \\
\text { menarik dan bersejarah. }\end{array}$ \\
\hline Industri batik & Masyarakat dapat lebih \\
& $\begin{array}{l}\text { memperkenalkan batik kepada } \\
\text { pengunjung. }\end{array}$ \\
\hline Industri & Wisatawan dapat melihat proses \\
jenang & pembuatan jenang. \\
\hline Jasa & Dengan keterbukaan masyarakat maka \\
& semakin banyak pemandu wisata yang \\
& ada. \\
\hline Tempat & Memperbanyak daya tampung bagi \\
makan & pengunjung yang akan makan dan \\
& jumlah tempat makan dengan kondisi \\
& yang layak. \\
\hline Akomodasi & Dengan tersedianya penginapan dalam \\
& jumlah banyak, maka memudahkan \\
\hline
\end{tabular}

\begin{tabular}{|c|c|}
\hline & Peluang (Opportunities) \\
\hline & $\begin{array}{l}\text { wisatawan yang akan berkunjung } \\
\text { kembali. }\end{array}$ \\
\hline $\begin{array}{l}\text { Toko } \\
\text { kelontong }\end{array}$ & $\begin{array}{l}\text { Memperbanyak barang yang dijual dan } \\
\text { jumlah toko, untuk memudahkan } \\
\text { wisatawan mendapatkan kebutuhan. }\end{array}$ \\
\hline $\begin{array}{l}\text { Pasar } \\
\text { tradisional }\end{array}$ & $\begin{array}{l}\text { Memudahkan wisatawan untuk } \\
\text { berbelanja. }\end{array}$ \\
\hline Salon & $\begin{array}{l}\text { Memudahkan wisatawan yang } \\
\text { memerlukan jasa kecantikan. }\end{array}$ \\
\hline Jalan & $\begin{array}{l}\text { Perlu dilakukan pelebaran jalan untuk } \\
\text { memudahkan akses di kampung ini. }\end{array}$ \\
\hline Transportasi & $\begin{array}{l}\text { Perlu penambahan jumlah sarana } \\
\text { transportasi menuju Kampung } \\
\text { Kedunggudel supaya waktu yang } \\
\text { dibutuhkan lebih efisien. }\end{array}$ \\
\hline $\begin{array}{l}\text { Papan } \\
\text { petunjuk } \\
\text { arah }\end{array}$ & $\begin{array}{l}\text { Penambahan papan petunjuk arah } \\
\text { dapat memudahkan wisatawan dalam } \\
\text { menemukan tujuan. }\end{array}$ \\
\hline Listrik & $\begin{array}{l}\text { Memudahkan aktifitas wisatawan yang } \\
\text { membutuhkan listrik. }\end{array}$ \\
\hline Air bersih & $\begin{array}{l}\text { Memudahkan wisatawan dalam } \\
\text { aktifitas yang membutuhkan air bersih. }\end{array}$ \\
\hline $\begin{array}{l}\text { Persediaan } \\
\text { air minum }\end{array}$ & $\begin{array}{l}\text { Memberi kemudahan untuk } \\
\text { mendapatkan air minum. }\end{array}$ \\
\hline Toilet & $\begin{array}{l}\text { Pengunjung tidak sekedar ke toilet, tapi } \\
\text { akan berkunjung juga ke masjid yang } \\
\text { bernilai sejarah. Kuantitas toilet perlu } \\
\text { ditambah di lokasi lain, agar } \\
\text { melancarkan kegiatan wisata. }\end{array}$ \\
\hline $\begin{array}{l}\text { Pelayanan } \\
\text { informasi }\end{array}$ & $\begin{array}{l}\text { Memaksimalkan informasi kepada } \\
\text { wisatawan }\end{array}$ \\
\hline Masjid & $\begin{array}{l}\text { Dapat dijadikan tujuan wisata untuk } \\
\text { lebih mengetahui sejarah Masjid } \\
\text { Darussalam, sehingga meningkatkan } \\
\text { jumlah jamaah sholat. }\end{array}$ \\
\hline $\begin{array}{l}\text { Kunjungan } \\
\text { pembelajaran }\end{array}$ & $\begin{array}{l}\text { Menambah wawasan proses } \\
\text { pembuatan batik dan jenang. }\end{array}$ \\
\hline
\end{tabular}

Sumber : analisis penulis, 2019

Table 6 Hasil penelitian berdasarkan ancaman

\begin{tabular}{ll}
\hline & Ancaman (Threatness) \\
\hline Sungai & Pada saat ini banyak tempat wisata di \\
Solo & kota lain yang berkembang dengan \\
& $\begin{array}{l}\text { memanfaatkan berbagai potensi alam, } \\
\text { salah satunya sungai yang berada di } \\
\text { Yogyakarta, yang ramai pengunjung. }\end{array}$ \\
\hline Industri batik & $\begin{array}{l}\text { Di Solo juga terdapat kampung wisata } \\
\text { batik yang sudah lebih berkembang, }\end{array}$ \\
& seperti di Laweyan dan Kauman. \\
\hline Industri & Kurangnya minat pemerintah setempat \\
jenang & dan warga untuk menyediakan tempat \\
& khusus bagi wisatawan yang ingin \\
& belajar proses pembuatan jenang. \\
\hline Jasa & Kurang canggihnya pemandu dalam \\
& memasarkan desa wisata melalui media \\
& sosial. \\
\hline Tempat & Di luar kampung ini sudah tersedia \\
makan & tempat makan yang layak. \\
\hline
\end{tabular}




\begin{tabular}{ll}
\hline & Ancaman (Threatness) \\
\hline Akomodasi & $\begin{array}{l}\text { Tidak selalu pemilik rumah dapat } \\
\text { menyewakan rumahnya untuk } \\
\text { penginapan. }\end{array}$ \\
\hline $\begin{array}{l}\text { Toko } \\
\text { kelontong }\end{array}$ & $\begin{array}{l}\text { Saat ini pembelian barang bisa dengan } \\
\text { mudah lewat aplikasi. }\end{array}$ \\
\hline Pasar & Masih belum ada ketertarikan \\
tradisional & pedagang untuk menambah jam buka. \\
\hline Salon & $\begin{array}{l}\text { Fasilitas salon saat ini sangat beragam } \\
\text { dengan teknologi yang berkembang.. }\end{array}$ \\
\hline Jalan & - \\
\hline Transportasi & $\begin{array}{l}\text { Wisatawan akan kesulitan untuk } \\
\text { mengunjungi semua industri dan akan }\end{array}$ \\
& kelelahan karena kurang sarana \\
transportasi.
\end{tabular}

Sumber : analisis penulis, 2019

\section{Matriks Analisa SWOT}

Matriks analisa SWOT dibedakan berdasarkan strategi SO, ST, WO dan WT sesuai tabel 7 sampai tabel 10 .

Tabel 7 Matriks analisa SWOT strategi SO

Strategi SO (Strengths-Opportunities)

Potensi 1. Mengelola sungai sebagai tujuan wisata supaya wisatawan mengetahui sejarah sungai terhadap perkembangan industri rumah tangga yang ada di Kampung Kedunggudel ini.

2. Menetapkan motif batik yang khas dari kampung ini supaya batik dari kampung ini lebih dikenal.

3. Membuat beberapa varian jenang yang khas supaya lebih tahan lama.

4. Melakukan kerjasama antar masyarakat supaya lebih banyak masyarakat yang tertarik menjadi pemandu.

1. Menyediakan tempat makan untuk memperbanyak daya tampung bag pengunjung dengan kondisi yang layak.

2. Menyediakan penginapan bagi pengunjung untuk memudahkan wisatawan yang akan menginap

3. Dengan jumlah toko yang banyak maka penjual dapat memperbanyak barang yang dijual untuk memudahkan melayani kebutuhan wisatawan.

\begin{tabular}{ll}
\hline Strategi SO (Strengths-Opportunities) \\
\hline 4. Terdapat pasar tradisional yang menjual \\
berbagai keperluan dapur dan rumah \\
tangga sehingga memudahkan wisatawan \\
untuk berbelanja. \\
5. Salon memiliki pelayanan aneka \\
perawatan rambut, rias pengantin dan \\
fotografi wedding untuk memudahkan \\
wisatawan yang memerlukan jasa \\
kecantikan. \\
\hline 1. Melebarkan jalan utama untuk \\
memudahkan akses di kampung ini. \\
2. Menambah jumlah transportasi umum \\
untuk menuju Kampung Kedunggudel \\
supaya waktu tempuh yang dibutuhkan \\
lebih efisien. \\
3. Menyediakan papan petunjuk arah untuk \\
memudahkan wisatawan dalam \\
menemukan tujuan. \\
4. Menjaga ketersediaan aliran listrik, air \\
bersih, air minum di Kampung \\
Kedunggudel untuk memudahkan aktifitas \\
wisatawan. \\
5. Menyediakan toilet umum selain di masjid, \\
dengan lokasi yang mudah di akses. \\
6. Memaksimalkan fungsi masjid. \\
Menambah atraksi wisata \\
a. Mengadakan susur sungai \\
b. Mengadakan konsep wisata yang \\
melibatkan pengunjung dalam proses \\
pembuatan batik ataupun jenang.
\end{tabular}

Sumber : analisis penulis, 2019

Tabel 8. Matriks analisa SWOT strategi ST Strategi ST (Strengths- Threatness)

Potensi 1. Mengoptimalkan fungsi sungai supaya tidak tertinggal oleh tempat wisata lainnya yang sudah memanfaatkan sungai sebagai tujuan wisata.

2. Mensosialisasikan sistem wisata yang sudah berkembang di Solo dengan mengunggulkan motif batik khas kampung ini.

3. Mensosialisasikan kepada pemerintah setempat dan warga supaya bersedia menyediakan tempat khusus bagi wisatawan yang ingin belajar proses pembuatan jenang, sebagai produk unggulan

4. Mensosialisasikan teknologi saat ini dalam memandu wisatawan.

Sarana 1. Menambah jumlah tempat makan supaya wisatawan tidak perlu membelinya di luar kampung ini.

2. Menambah jumlah penginapan supaya jumlah wisatawan dan jumlah penginapan seimbang.

3. Mempermudah pembelian di toko kelontong untuk mengurangi wisatawan membeli barang melalu aplikasi

4. Menambah penjualan supaya pedagang tertarik menambah jam buka. 


\begin{tabular}{ll}
\hline & Strategi ST (Strengths- Threatness) \\
\hline & 5. Meningkatkan fasilitas salon dengan \\
teknologi yang berkembang.
\end{tabular}

Sumber : analisis penulis, 2019

Tabel 9 Matriks analisa SWOT strategi WO

Strategi WO (Weakness- Opportunities)

\begin{tabular}{ll} 
& Strategi WO (Weakness- Opportunities) \\
\hline Potensi & \begin{tabular}{l} 
1. Bekerjasama antara pemerintah dan \\
masyarakat untuk mengembangkan fungsi \\
sungai lebih beragam sebagai magnet, \\
agar jumlah pengunjung meningkat \\
2. Masyarakat dapat lebih memperkenalkan \\
motif batik khas kampung ini kepada \\
pengunjung \\
3. Industri jenang dapat membuat jenang \\
yang tahan lama dan dapat dipelajari oleh \\
wisatawan. \\
4. Melakukan sosialisasi kepada masyarakat \\
untuk meningkatkan jumlah pemandu \\
wisata. \\
\hline 1. Menyediakan tempat makan yang mampu \\
menampung lebih dari 20 orang. \\
2. Menambah jumlah rumah untuk \\
penginapan untuk menyesuaikan jumlah \\
wisatawan. \\
3. Menambah kuantitas dan kualitas barang \\
yang dijual serta jam buka pasar. \\
4. Menambah jumlah salon yang memiliki \\
berbagai pelayanan kecantikan.
\end{tabular} \\
\hline 1. Melebarkan jalan supaya dapat dilewati \\
bis dua arah \\
2. Menambah jumlah sarana transportasi \\
menuju Kampung Kedunggudel. \\
3. Menyediakan papan petunjuk arah. \\
4. Menyediakan genset di beberapa titik, \\
5. Menyediakan cadangan air. \\
6. Memudahkan akses menuju toilet umum. \\
7. Menyediakan pusat pelayanan informasi \\
yang strategis dan lebih dekat dengan \\
permukiman warga.
\end{tabular}

Sumber : analisis penulis, 2019
Tabel 10 Matriks analisa SWOT strategi WT

Strategi WT (Weakness- Threatness)

\begin{tabular}{ll}
\hline Potensi & 1. Memfungsikan sungai sebagai tujuan \\
& wisata supaya wisatawan tertarik \\
& mengunjungi. \\
& 2. Membuat motif batik yang khas. \\
& 3. Membuat jenang yang dapat bertahan \\
& lama dengan berbagai varian, sebagai \\
& bentuk pengembangan kreativitas. \\
& 4. Meningkatkan kreativitas dalam memandu \\
& wisata supaya banyak masyarakat tertarik. \\
\hline Sarana & 1. Menyediakan tempat makan yang mampu \\
& menampung lebih dari 20 orang agar \\
& wisatawan tidak perlu membelinya di luar \\
kampung ini. \\
2. Menambah jumlah rumah untuk \\
penginapan, sebagai upaya mengatasi \\
masalah pemilik rumah yang tidak bisa \\
menyewakan rumahnya untuk \\
penginapan. \\
3. Melengkapi barang jualan untuk \\
menghindari wisatawan belanja melalui \\
aplikasi. \\
4. Menambah jumlah salon dengan berbagai \\
fasilitas kecantikan dengan menggunakan \\
teknologi yang berkembang.
\end{tabular}

Sumber : analisis penulis, 2019

\section{KESIMPULAN}

Berdasarkan analisis yang telah dilakukan dapat disimpulkan bahwa, Kampung Kedunggudel memiliki: 1) potensi alam berupa Sungai Bengawan Solo, 2) potensi budaya berupa industri batik dan industri jenang, 3) potensi manusia berupa jasa pemandu wisata, namun belum optimal dalam pengembangannya. Potensi tersebut belum didukung sepenuhnya oleh ketersediaan sarana prasarana, baik untuk akomodasi maupun transportasi. Kerjasama antara pemerintah daerah dan masyarakat harus ditumbuhkan agar ketersediaan potensi dapat dikembangkan dan kekurangan sarana prasarana dapat teratasi. 
Sosialisasi tentang daya tarik yang ada di Kampung Kedunggudel untuk memberikan wawasan kepada masyarakat sekaligus menarik pihak pemerintah agar terlibat di dalamnya. Hal ini sangat penting sebagai upaya memberikan informasi dan contoh kerjasama pengembangan dan pemanfaatan daya tarik. Langkah yang perlu dilakukan adalah kerjasama dan diskusi bersama secara rutin untuk memantau progress yang sudah dicapai dan yang belum dicapai guna meningkatkan kualitas.

Pelengkapan sarana dan prasaran yang perlu diupakayan adalah: 1) menambah daya tampung tempat makan supaya mampu menampung orang dengan jumlah besar, 2) memperbanyak jumlah akomodasi, 3) melengkapi barang untuk dijual, 4) menambah sarana penunjang, 5) pelebaran jalan, 6) penambahan sarana transportasi wisata dan umum, 7) pengadaan papan petunjuk arah yang menunjukkan letak tujuan wisata, 8) pengadaan toilet umum di beberapa sudut kampong, 9) menambah tempat pelayanan informasi yang mudah dijangkau wisatawan, 10) pengadaan genset untuk mengatasi jika terjadi pemadaman listrik.

\section{DAFTAR PUSTAKA}

Atmoko, T. P. (2014). Strategi pengembangan potensi desa wisata Brajan Kabupaten Sleman. Jurnal media wisata , 148.

Ghani, Y. A. (2017). Pengembangan Sarana Prasarana Destinasi Pariwisata berbasis Budaya di Jawa Barat. Jurnal Pariwisata, 24-25.

Hary Hermawan, E. B. (2017). Buku panduan wisata edukasi kampung tulip. Bandung: Program Pemberdayaan Masyarakat STP ARS Internasional Bandung.

Pujani, I. N. (2017). Kajian Penyusunan kriteria-kriteria desa wisata sebagai instrumen dasar pengembangan desa wisata. Jurnal Analisis Pariwisata, 3.

Ramadhan, N. (2016). Pengembangan atraksi pada objek wisata Danau Bandar Khayangan Lembah
Sari, Pekanbaru. Bandung: Sekolah Tinggi Pariwisata.

Rengkung, F. G. (2019). Analisis kebutuhan prasarana dan sarana dalam pengembangan kawasan wisata bahari di Pulau Maitara Kota Tidore Kepaluan. Jurnal Spasial, 582.

Setyawan, R. (2015). Penerapan analisis SWOT sebagai landasan merumuskan strategi pemasaran usaha jasa sewa mobil "AMIN-AMIN" transport Tours and Travel Ambarketawang Sleman Yogyakarta. Yogyakarta: pendidikan ekonomi fakultas ekonomi Universitas Negeri Yogyakarta. 